\title{
RATIONALIZATION OF IRRIGATION WATER IN AGRICULTURAL SECTOR THROUGH INTEGRATED WATER MANAGEMENT AND COMMUNITY PARTICIPATION
}

\author{
Fouad A.F. Khalil ${ }^{1}$ and Rashad Abouenein ${ }^{2}$
}

\author{
1- Soil, Water and Environment Research Institute, Agriculture Research \\ Center; Egypt \\ 2- Field Crops Research Institute, Agriculture Research Center; Egypt
}

\begin{abstract}
The limited water and land resource in Egypt is faced with the challenge of currently feeding more than 85 million people and about 100 million by the year 2025. As there are no new water resources expected in the near future and that more water is diverted to domestic and industrial purposes. There is an urgent need to increase water productivity to meet the increasing demand for food and food security. In this respect, National Agricultural Research System (NARS) in Egypt, had joined hands with the International Center for Agricultural Research in the Dry Areas (ICARDA) to initiate a community-based participatory approach for identifying and disseminating interventions for increasing water productivity. Based on the socio economic and technical criteria four farms at Monofia Governorate (Nile Delta) were selected to research options for improving water productivity (WP) at the farm and community scheme levels. New interventions included:

1- Planting wheat, berseem and maize crops on wide furrows (raised -seed bed).

2- Irrigating wheat, berseem clover and maize under deficit irrigation. The field trials were executed in 2007/2008 and 2008/2009 seasons. The most important findings could be as follows :-

* Planting wheat, berseem and maize crops on raised - seed bed saved water, increased yield and improved WP as compared to farmer practice.

* Under irrigation regime at 1.2 ETc and deficit irrigation at 0.70 ETc, the reductions in water applied for wheat and berseem crops reached 6.90 and $39.85 \%$ and 5.77 and $26.69 \%$, respectively, comparable with the farmer practice. Similar trend was noticed with maize crop where the reductions in water applied, due to irrigating at 1.2 and $.075 \mathrm{ETc}$, ranged from 5.89 to $25.54 \%$, compared with farmer practice. In 2007/2008 season full and deficit irrigation $(0.70 \mathrm{ETc})$ regimes slightly reduced wheat grain yield by 0.83 and $2.65 \%$, whereas in 2008/2009 season, full and deficit irrigation $(0.70 \mathrm{ETc})$ regimes increased wheat grain yield by 6.78 and $1.95 \%$, respectively, in comparison with farmer practice. In 2008 season, maize yield was reduced by 8.01 and $12.49 \%$ due to full and deficit ( 0.75 full irrigation) irrigation regimes, respectively, as compared with farmer practice. In 2009 season, the trend was differed where full irrigation exhibited higher maize grain yield value $(7.34 \%)$ and deficit irrigation still reducing the maize grain yield by $28.85 \%$, in comparison with farmer practice.
\end{abstract}

Fayoum J. Agric. Res. \& Dev., Vol. 26, No.2, July, 2012 
Water productivity value for wheat under full irrigation regime(1.2ETc) ranged from 6.25 to $19.88 \%$ and, while under deficit irrigation $(0.70 \mathrm{ETc})$, the figures ranged from 46.05 to $61.25 \%$, comparable with farmer practice. Water productivity values for berseem were increased by12.40 and $25.16 \%$ higher than those under farmer practice, respectively, due to irrigating at 1.2 and 0.70 ETc regimes. Full and deficit irrigation $(0.75$ full irrigation) regimes still improving WP for maize to be 24.36 and $43.13 \%$ in 2008 season and 13.79 and $21.41 \%$ in 2009 one, respectively, as compared with farmer practice.

Key words: Wheat crop-maize crop-raised-seed bed-deficit irrigation-water productivity

\section{INTRODUCTION}

Water availability is the most limiting factor for increasing agricultural production in Egypt. Agricultural sector is receiving the lion's share of the available water, since over $80 \%$ of the water sources are allocated for agriculture. However, the demand on water resources in this field is growing up due to the expansion of irrigated areas to provide the increasing population with needed food and fibers. The dilemma to be faced is how to increase the water supply to the agriculture sector in the time that all the other sectoral water uses are suffering from water shortages. The solution lies in the agricultural sector itself through increasing on-farm water productivity, i.e., decreasing water losses and, thereby, making good water-saving that compensates for the water shortages. In another word, obtaining more crop production from the same amount of water or more crops per drop expressing the physical productivity of water in agriculture. Optimum crop yields under deficient irrigation practices can be obtained by allowing a certain level of yield reduction of a given crop while higher returns can be obtained with saved water, which, can be diverted to irrigate other areas or crops. Therefore, this innovative concept is given different names such as deficient irrigation, deficient evapotranspiration irrigation and limited irrigation and the like, English $\boldsymbol{e t}$ al. 1990. Deficient irrigation practice is now widely planned and used in many countries. Furthermore, Hamidreza Salemi et al. (2011) irrigating maize with 100, 80 and $60 \%$ of crop evapotranspiration reported that the corresponding grain yield values amounted to 9450,9250 and $8377 \mathrm{kgha}^{-1}$, comparable with conventional irrigation $\left(9271 \mathrm{kgha}^{-1}\right)$. The authors added that $80 \%$ of crop evapotranspiration is the most advantageous treatment when water is not limited. However, to save water and to get higher water productivity values, $60 \%$ irrigation level is recommended. Zwart and Bastiaanssen (2004) reported that the range of crop Water Productivity (WP) of maize, based on a review of 84 literature sources, is very large $(1.1-2.7 \mathrm{~kg}$ $\mathrm{m}^{-3}$ ) and it thus offers new water management practices for increasing crop production with $20-40 \%$ less water resources. The authors concluded that in order to achieve optimum crop WP in water short regions, it would be wise to irrigate maize and wheat with less water. In addition, Geerts and Raes (2009) had reviewed many research from around the world and confirmed that deficit irrigation is successful in increasing WP for various crops without causing severe yield reductions. Moreover, Ouda et al. (2010) stated that water

Fayoum J. Agric. Res. \& Dev., Vol. 26, No.2, July, 2012 
RATIONALIZATION OF IRRIGATION WATER IN AGRICULTURAL... 18 productivity for berseem clover was gradually increased due to deficit irrigation treatments e.g. 95, 90, 85, and $80 \%$ of full irrigation.

Irrigation technologies and irrigation scheduling may be adapted for more-effective and rational uses of limited supplies of water.. It is necessary to develop new irrigation approaches and schemes, not necessarily based on full crop water requirement, but ones designed to ensure the optimal use of allocated water. Ghani Akbar et al. (2010) reported that narrow beds $(65 \mathrm{~cm})$ used $3-7 \%$ less water than the basins while the medium $(130 \mathrm{~cm})$ and wide beds $(180 \mathrm{~cm})$ used $16-17 \%$ and $18-22 \%$ less water, respectively, comparable with traditional flat basin system. Moreover, Fahong et al. (2011) stated that wheat productivity increase under bed planting ranged from 6.6 to $12 \%$ over 5 locations, comparable with basin practice and such yield increase is attributed to optimizing wheat morphological traits and enhance plant lodging resistance. Stone et al. (1982) stated that wide- spaced furrow irrigation method reduced evapotranspiration losses and can reduce water requirements.and such codition could be attributed to applying the irrigation water into the root zone while maintaining a relatively dry soil surface.

This work was conducted aiming at introducing new, simple and practicable techniques with the involvement and partnership of farmers to increase crop water productivity for wheat, berseem and maize crops. On-farm improvement concerning water management to reduce water losses and achieve better water-saving was considered.

\section{MATERIALS AND METHODS:}

On-farm trials were conducted in four farms at Monofia Governorate to identify and test with communities the interventions that improve water productivity and sustain its use and generate the data required for an economic impact assessment and in modeling aspects and to support the writing of water productivity (WP) for three major field crops namely wheat, berseem and maize .

The interventions tested in the selected farmes for developing water-saving technologies were as follows:.

$\mathrm{I}_{1}$ : Farmer traditional method in the site.

$\mathrm{I}_{2}$ : Required irrigation amount in the site (1.2 ET).

$\mathrm{I}_{3}$ : Deficit irrigation of the required irrigation .

$\mathrm{I}_{3}$.a. Deficit irrigation ( 0.70 full irrigation) with wheat and berseem crops.

$\mathrm{I}_{3}$.b. Deficit irrigation ( 0.75 full irrigation) with maize crop. and

$\mathrm{I}_{4}$ : Raised-bed irrigation method for growing wheat, berseem clover and maize (wheat on raised bed was in hills or broadcasting before implementing raised bed).

Both adopted irrigation practices and irrigation regimes were tested in the Randomized Complete Block Design with four replicates. The plot experimental area equals $100 \mathrm{~m}^{2}$. All of the agronomic practices i.e. seed bed preparation, seeding rate, $\mathrm{N} \& \mathrm{P}$ fertilization, weeds and pests control.......etc were done as common in the area.

Water requirement calculation:

CROPWAT (version 4.3) is a computer program uses PenmanMonteith combination method for calculating reference evapotranspiration (ETo) values. These estimates are used in crop water requirements and irrigation scheduling calculations (Smith,1992). Agroclimatological data for Monufia Governorate are shown in Table 1 .

Fayoum J. Agric. Res. \& Dev., Vol. 26, No.2, July, 2012 
Reference evapotranspiration (ETo)

The FAO Penman-Monteith method can be expressed as :-

$$
\boldsymbol{E T o}=\frac{0.408 \Delta(\boldsymbol{R n}-\boldsymbol{G})+\gamma \frac{900}{\boldsymbol{T}+273} \boldsymbol{u} 2(\boldsymbol{e s}-\boldsymbol{e a})}{\Delta+\gamma(1+0.34 \boldsymbol{u} 2)}
$$

Where:

ETo: reference evapotranspiration $\left(\mathrm{mm} \mathrm{day}^{-1}\right)$

$\mathrm{Rn}$ : net radiation at the crop surface $\left(\mathrm{MJ} \mathrm{m}^{-2}\right.$ day $\left.^{-1}\right)$

$\mathrm{G}: \quad$ soil heat flux density $\left(\mathrm{MJ} \mathrm{m}^{-2}\right.$ day $\left.^{-1}\right)$

T: $\quad$ mean daily air temperature at $2 \mathrm{~m}$ height $\left({ }^{\circ} \mathrm{C}\right)$

$\mathrm{u} 2$ : $\quad$ wind speed at $2 \mathrm{~m}$ height $\left(\mathrm{m} \mathrm{s}^{-1}\right)$

es: $\quad$ saturation vapor pressure $(\mathrm{kPa})$

ea: actual vapor pressure $(\mathrm{kPa})$

es-ea: vapor pressure deficit $(\mathrm{kPa})$

$\Delta: \quad$ slope vapor pressure-temperature curve $\left(\mathrm{kPa}^{\circ} \mathrm{C}^{-1}\right)$

$\gamma: \quad$ psychrometric constant $\left(\mathrm{kPa}^{\circ} \mathrm{C}^{-1}\right)$

Table 1 : Agroclimatological data for Monufia Governorate (Average 1997-2006)*

\begin{tabular}{|l|c|c|c|c|c|c|}
\hline Month & T. max. & T. min. & W.S & R.H & R.F & Epan \\
\hline September & 33.1 & 20.0 & 172.8 & 59 & 0.0 & 6.1 \\
\hline October & 29.5 & 17.2 & 172.8 & 64 & 0.0 & 4.7 \\
\hline November & 25.0 & 13.3 & 172.8 & 64 & 1.6 & 2.8 \\
\hline December & 21.0 & 9.8 & 172.8 & 66 & 4.1 & 2.1 \\
\hline January & 19.4 & 7.5 & 207.4 & 65 & 4.9 & 1.8 \\
\hline February & 19.9 & 7.7 & 207.4 & 64 & 4.6 & 2.5 \\
\hline March & 22.6 & 9.2 & 216.0 & 63 & 1.4 & 3.6 \\
\hline April & 27.2 & 12.2 & 198.7 & 56 & 0.8 & 5.3 \\
\hline May & 32.0 & 16.4 & 190.1 & 56 & 0.0 & 7.2 \\
\hline
\end{tabular}

Tmax and Tmin $=$ Maximum and minimum temperatures $\left(C^{\circ}, W S=\right.$ wind speed $\left(\mathrm{msec}^{-1}\right)$,

$R H=$ Relative humidity, $R F=$ Rain fall $(\mathrm{mm})$ and Epan $=$ Pan evaporation $\left(\right.$ mmday $\left.^{-1}\right)$

* Source : Water requirements and field irrigation research department

\section{2- Crop water requirements:}

Crop water requirements (ETcrop) over the growing season are determined from ETo and crop coefficient (Kc) according to the following equation:

Crop water requirement $($ ETcrop $)=$ ETo $X$ Kc / Irrigation efficiency

Fayoum J. Agric. Res. \& Dev., Vol. 26, No.2, July, 2012 
RESULTS AND DISCUSSION

\section{Wheat crop}

\section{1.a. Raised- seed bed (Wide Furrows) irrigation:}

Data in Table 2 revealed that raised - seed bed irrigation technique and the assessed irrigation regimes seemed to reduce irrigation water applied for wheat crop, comparable with the farmer irrigation practice. The reduction in water applied, as wheat was grown in hills, on raised - seed bed reached 28.49 and $24.07 \%$, as compared with farmer practice, respectively, in 2007/2008 and 20082009 growing seasons. Furthermore, growing wheat in broadcasting system on raised - seed bed in 2008/2009 season, resulted in water saving amounted to $23.59 \%$ higher than the farmer practice. It is obvious that irrigation wheat crop via raised - seed bed technique leads to appreciable saving in water applied. These findings are in parallel with those reported by Stone et al. (1982) who stated that wide- spaced furrow irrigation method applies water to the root zone while maintaining a relatively dry soil surface. This condition reduced evapotranspiration losses and can reduce water requirements. In addition, Fahong et al. (2004) found that, changing flat planting under basin irrigation to raised -bed planting and furrow irrigation, saved $17 \%$ of applied water for wheat crop. Ghani Akbar et al. (2010) reported that narrow beds $(65 \mathrm{~cm})$ used $3-7 \%$ less water than the basins.

While, the medium $(130 \mathrm{~cm})$ and wide beds $(180 \mathrm{~cm})$ used $16-17 \%$ and $18-22 \%$ less, respectively, comparable with traditional flat basin system. Walker and Skogerboe (1987) reported that using furrows or bed - and furrows irrigation methods has considerable advantages over basin irrigation systems, because they provide better on-farm water management, evaporative losses can be reduced, and higher efficiencies are in general achieved. Moreover, Ahmad et al. (2010), evaluate different irrigation techniques (border/flat, bed and furrow method) to irrigate wheat crop, and found that bed furrow method consumed about $35.6 \%$ less water, as compared to flat border irrigation method.

Data in Table 2 illustrated that wheat yield tended to increase due to irrigating using raised - seed bed techniques, in comparison with farmer practice. The increases in wheat yield comprised 5.07 and $6.47 \%$, respectively, in 2007/2008 and 2008/2009 seasons, as wheat was grown in hills system on raised bed, comparable with farmer practice. Similar finding was true, as wheat was grown in broadcasting system on the raised- seed bed in 2008/2009 season, where the wheat yield was increased by $9.51 \%$, as compared with that under farmer practice. In this sense, Ghani Akbar et al. (2010) found that wide $(180 \mathrm{~cm})$ beds produced higher wheat $(15 \%)$ than traditional flat basin system. Moreover, Fahong et al. (2011) stated that wheat productivity increases under bed planting ranged from 6.6 to $12 \%$ over 5 locations, comparable with basin practice and such yield increase is attributed to optimizing wheat morphological traits and enhance plant lodging resistance.

Fayoum J. Agric. Res. \& Dev., Vol. 26, No.2, July, 2012 
Fouad A.F. Khalil and Rashad Abouenein

Table 2: Applied irrigation water, grain yield and water productivity for wheat crop in 2008/2009 and 2008/ 2009 seasons

\begin{tabular}{|c|c|c|c|c|c|}
\hline \multirow[t]{3}{*}{$\begin{array}{l}\text { Irrigation } \\
\text { practice }\end{array}$} & $\begin{array}{l}\text { Farmer } \\
\text { practice }\end{array}$ & $\begin{array}{c}\text { Full } \\
\text { irrigation } \\
(1.2 \text { ETc })\end{array}$ & $\begin{array}{l}0.70 \text { full } \\
\text { irrigation }\end{array}$ & $\begin{array}{l}\text { Wide } \\
\text { furrows } \\
\text { (hills) }\end{array}$ & $\begin{array}{l}\text { Wide furrows } \\
\text { (broadcasting) }\end{array}$ \\
\hline & \multicolumn{5}{|c|}{$2007-2008$ season } \\
\hline & \multicolumn{5}{|c|}{ Applied water, mm } \\
\hline Farm 1 & 540 & 500 & 436 & 400 & - \\
\hline Farm 2 & 557 & 530 & 430 & 416 & - \\
\hline Farm 3 & 511 & 490 & 396 & 344 & - \\
\hline Farm 4 & 540 & 480 & 420 & 376 & - \\
\hline \multirow[t]{2}{*}{ Average } & 537 & 500 & 323 & 384 & - \\
\hline & \multicolumn{5}{|c|}{ Grain yield, tha $^{-1}$} \\
\hline Farm 1 & 9.429 & 9.464 & 9.321 & 8.964 & - \\
\hline Farm 2 & 7.607 & 7.393 & 8.321 & 8.607 & - \\
\hline Farm 3 & 7.750 & 6.646 & 7.679 & 8.393 & - \\
\hline Farm 4 & 9.440 & 10.440 & 8.000 & 10.00 & - \\
\hline \multirow[t]{2}{*}{ Average } & 8.557 & 8.486 & 8.330 & 8.991 & - \\
\hline & \multicolumn{5}{|c|}{ Water productivity, $\mathrm{Kgm}^{-5}$} \\
\hline Farm 1 & 1.75 & 1.89 & 2.14 & 2.24 & - \\
\hline Farm 2 & 1.37 & 1.39 & 1.94 & 2.07 & - \\
\hline Farm 3 & 1.52 & 1.36 & 1.94 & 2.44 & - \\
\hline Farm 4 & 1.75 & 2.18 & 1.90 & 2.66 & - \\
\hline \multirow[t]{3}{*}{ Average } & 1.60 & 1.70 & 2.58 & 2.35 & - \\
\hline & \multicolumn{5}{|c|}{$2008-2009$ season } \\
\hline & \multicolumn{5}{|c|}{ Applied water, mm } \\
\hline Farm 1 & 675 & 595 & 466 & 490 & 493 \\
\hline Farm 2 & 633 & 562 & 443 & 478 & 479 \\
\hline Farm 3 & 608 & 570 & 449 & 487 & 490 \\
\hline Farm 4 & 560 & 487 & 379 & 424 & 429 \\
\hline \multirow[t]{2}{*}{ Average } & 619 & 554 & 434 & 470 & 473 \\
\hline & \multicolumn{5}{|c|}{ Grain yield, tha $^{-1}$} \\
\hline Farm 1 & 6.064 & 6.399 & 6.239 & 6.472 & 6.668 \\
\hline Farm 2 & 6.074 & 6.449 & 6.110 & 6.340 & 6.614 \\
\hline Farm 3 & 6.373 & 6.415 & 5.920 & 6.442 & 6.550 \\
\hline Farm 4 & 6.148 & 7.070 & 6.870 & 7.003 & 7.170 \\
\hline \multirow[t]{2}{*}{ Average } & 6.165 & 6.583 & 6.285 & 6.564 & 6.751 \\
\hline & \multicolumn{5}{|c|}{ Water productivity, $\mathrm{Kgm}^{-3}$} \\
\hline Farm 1 & 0.898 & 1.075 & 1.339 & 1.321 & 1.353 \\
\hline Farm 2 & 0.960 & 1.148 & 1.379 & 1.326 & 1.381 \\
\hline Farm 3 & 1.048 & 1.125 & 1.318 & 1.323 & 1.337 \\
\hline Farm 4 & 1.098 & 1.452 & 1.813 & 1.652 & 1.670 \\
\hline Average & 1.001 & 1.200 & 1.462 & 1.406 & 1.435 \\
\hline
\end{tabular}

Water productivity for wheat crop seemed to be higher, under raised seed bed techniques, than that under the farmer practice, Table 2. Growing wheat on raised bed, in hills system, water productivity values were 46.88 and $40.46 \%$ higher than those under farmer practice, respectively, in 2007/2008 and 2008/2009 seasons. Similar trend for water productivity was noticed due

Fayoum J. Agric. Res. \& Dev., Vol. 26, No.2, July, 2012 
to growing wheat crop on raised bed, broadcasting system in 2008/2009 season, where water productivity value increased by $43.36 \%$, comparable with the farmer practice. In connection, Khan et al. (2007), stated that although broad furrow irrigation system seems to consume maximum energy, it achieves the highest water use efficiency for wheat crop, comparable with basin and narrow bed irrigation systems. In addition Ghani Akbar et al. (2010) in North-West Pakistan, stated that permanent raised bed generally resulted in higher Gross Production Water Use Indices $(\mathrm{kg} / \mathrm{ha} / \mathrm{mm})$, compared to traditional flat basin system.

\section{1.b. Deficit Irrigation}

In the context of improving water productivity, there is a growing interest in deficit irrigation, which is an irrigation practice whereby water supply is reduced below maximum levels and mild stress is allowed with minimal effects on yield. The assessed irrigation regimes e.g. full irrigation $(1.2 \mathrm{ETc})$ and deficit irrigation $(0.70 \mathrm{ETc})$ seemed to reduce the irrigation water applied to wheat crop, Table 2 . The reduction in applied water reached 6.90 and $39.85 \%$ in $2007 / 2008$ season and comprised 10.51 and $29.89 \%$ in 2008/2009 one, respectively, under full irrigation and deficit irrigation $(0.70$ ETc) regimes, as compared with the farmer practice. Abdou et al. (2011) recorded that irrigating wheat crop at 1.2 Epan produced the highest values of $\mathrm{ET}_{\mathrm{C}}$ which ranged from 41.03 to $43.50 \mathrm{~cm}$, while irrigating at 0.8 Epan the ETc ranged from 37.41 to $40.98 \mathrm{~cm}$.

Data in Table 2 revealed that both full and deficit irrigation $(0.70 \mathrm{ETc})$ regimes slightly reduced wheat grain yield by 0.83 and $2.65 \%$, respectively, in $2007 / 2008$ season, as compared with the farmer practice. The trend was reversed in 2008/2009 season where the wheat grain yield values seemed to increase by 6.78 and $1.95 \%$, respectively, under full irrigation and 0.70 full irrigation, comparable with the farmer practice. In connection, Stegman et al. (1980) stated that deficit irrigation ensures optimum and sustainable agricultural production, in a given region and maximizes incomes of the growers if irrigation water resources are limited or expensive. Abdou et al. (2011) found that irrigating wheat crop at 1.2 Epan resulted in the highest averages of wheat grains and straw yields.

In 2007/2008 season, water productivity value under fulll irrigation regime did not greatly alter $(6.25 \%)$, as compared with that recorded for farmer practice. Nevertheless, deficit irrigation ( 0.70 full irrigation) exhibited higher water productivity value comprised $61.25 \%$ than that obtained with farmer practice. In 2008/2009 season, both full and deficit irrigation regimes resulted in higher water productivity values, comparable with farmer practice, where the increases amounted to 19.88 and $46.05 \%$, respectively. Abdou et al. (2011) revealed that the highest WUE values for wheat crop ranged from 1.17 to $1.19 \mathrm{~kg}_{\text {grainsm }}{ }^{-3}$ water consumed were detected from irrigating wheat at

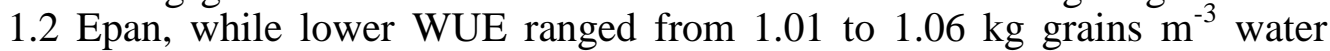
consumed was due to irrigation at 0.8 Epan and the authors attributed such lower WUE to the drastic reduction in grain yield.

\section{Maize crop}

\section{2.a. Raised-bed (Wide Furrows)}

Data in Table 3 illustrated that raised - seed bed irrigation technique and the assessed irrigation regimes seemed to reduce irrigation water applied for maize crop, comparable with the farmer irrigation practice. The reduction in water applied, as wheat was grown in hills, on raised - seed bed reached

Fayoum J. Agric. Res. \& Dev., Vol. 26, No.2, July, 2012 
25.14 and $19.10 \%$, as compared with farmer practice, in 2008 and 2009 growing seasons, respectively,. Furthermore, growing. It is obvious that irrigation maize crop under raised - seed bed technique leads to appreciable saving in water applied. These findings are in parallel with those reported by Stone et al. (1982) who stated that wide- spaced furrow irrigation method reduced evapotranspiration losses and can reduce water requirements and such codition could be attributed to applying the irrigation water into the root zone while maintaining a relatively dry soil surface. In addition, in Egypt, ElMarsafawy et al. (1998), found that irrigation with $140 \mathrm{~cm}$ apart furrows, comparable with $70 \mathrm{~cm}$ apart furrows, resulted in $8 \%$ reduction in evapotranspiration and improved root environment which increased absorption media and encouraged growth characteristics for maize crop. Furthermore, Wentworth and Jacobs (2001) with maize crop, found that water saving using permenant beds irrigation amounted $31.1 \%$, comparable with furrow irrigation. In connection, Ghani Akbar et al. (2010) reported that narrow beds $(65 \mathrm{~cm})$ used $6.65 \%$ less water, while the medium $(130 \mathrm{~cm})$ and wide beds $(180 \mathrm{~cm})$ used $15.93 \%$ and $17.50 \%$ less water applied for maize crop, respectively, comparable with traditional flat basin system.

Data in Table 3 illustrated that maize yield tended to increase due to irrigating using raised - seed bed techniques, in comparison with farmer practice. The increases in maize yield comprised 6.04 and $7.25 \%$, respectively, in 2008 and 2009 seasons, as maize was grown on raised- seed bed, comparable with farmer practice. In this sense, Ghani Akbar et al. (2010) found that wide (180 $\mathrm{cm})$ beds produced higher maize yield $(26.47 \%)$ than traditional flat basin system.

Water productivity (WP) for maize crop seemed to be higher, under raised - seed bed technique, than that under the farmer practice, Table 3. Growing maize on raised bed, water productivity values were 53.59 and $34.09 \%$ higher than those under farmer practice, respectively, in 2008 and 2009 seasons. In connection, Wentworth and Jacobs (2001) stated that water productivity for maize crop was enhanced due to permenant beds irrigation by 31.34\% over that reported under furrow irrigation. Ghani Akbar et al. (2010) in North-West Pakistan, stated that growing maize on permanent raised bed generally resulted in higher Gross Production Water Use Indices $(\mathrm{kg} / \mathrm{ha} / \mathrm{mm})$, compared to traditional flat basin system.

\section{2.b. Deficit Irrigation}

Data in Table 3 revealed that irrigation water applied for maize under full and deficit(0.75 full irrigation) irrigation regimes were lower by 10.10 and $25.54 \%$ in 2008 season and by 5.89 and $20.04 \%$ in 2009 one, comparable with farmer practice, respectively. Furthermore, Hamidreza Salemi et al. (2011) irrigated maize with 100, 80 and $60 \%$ of crop evapotranspiration and found that the water applied values were 9851,7881 and $5911 \mathrm{~m}^{3} \mathrm{ha}^{-1}$ compared with conventional irrigation $\left(10836 \mathrm{~m}^{3} \mathrm{ha}^{-1}\right)$.

Fayoum J. Agric. Res. \& Dev., Vol. 26, No.2, July, 2012 
RATIONALIZATION OF IRRIGATION WATER IN AGRICULTURAL.... 24

Table 3: Applied irrigation water, grain yield and water productivity for maize crop in 2008 and 2009 seasons

\begin{tabular}{|c|c|c|c|c|}
\hline \multirow[t]{3}{*}{$\begin{array}{l}\text { Irrigation } \\
\text { practice }\end{array}$} & $\begin{array}{l}\text { Farmer } \\
\text { practice }\end{array}$ & $\begin{array}{c}\text { Full irrigation } \\
(1.2 \mathrm{ETc})\end{array}$ & $\begin{array}{c}0.75 \text { full } \\
\text { irrigation }\end{array}$ & $\begin{array}{l}\text { Wide } \\
\text { furrows }\end{array}$ \\
\hline & \multicolumn{4}{|c|}{2008 season } \\
\hline & \multicolumn{4}{|c|}{ Applied water, mm } \\
\hline Farm 1 & 574 & 564 & 463 & 451 \\
\hline Farm 2 & 656 & 600 & 499 & 483 \\
\hline Farm 3 & 655 & 563 & 483 & 498 \\
\hline Farm 4 & 648 & 550 & 441 & 464 \\
\hline Average & 633.2 & 569.3 & 471.5 & 474.0 \\
\hline & \multicolumn{4}{|c|}{ Grain yield, tha ${ }^{-1}$} \\
\hline Farm 1 & 10.10 & 10.00 & 9.64 & 10.50 \\
\hline Farm 2 & 9.41 & 8.23 & 7.75 & 7.23 \\
\hline Farm 3 & 9.64 & 8.06 & 7.69 & 9.44 \\
\hline Farm 4 & 9.28 & 9.08 & 8.55 & 9.15 \\
\hline Average & 9.61 & 8.84 & 8.41 & 9.03 \\
\hline & \multicolumn{4}{|c|}{ Water productivity, $\mathrm{Kg} \backslash \mathrm{m}^{3}$} \\
\hline Farm 1 & 1.760 & 1.773 & 2.082 & 2.328 \\
\hline Farm 2 & 1.434 & 1.372 & 1.553 & 1.497 \\
\hline Farm 3 & 1.472 & 1.432 & 1.592 & 1.896 \\
\hline Farm 4 & 1.432 & 1.651 & 1.939 & 1.972 \\
\hline Average & 1.252 & 1.557 & 1.792 & 1.923 \\
\hline & \multicolumn{4}{|c|}{2009 season } \\
\hline & \multicolumn{4}{|c|}{ Applied water, mm } \\
\hline Farm 1 & 825 & 761 & 651 & 676 \\
\hline Farm 2 & 776 & 740 & 625 & 619 \\
\hline Farm 3 & 758 & 708 & 600 & 592 \\
\hline Farm 4 & 820 & 783 & 666 & 685 \\
\hline Average & 794.8 & 748.0 & 635.5 & 643.0 \\
\hline & \multicolumn{4}{|c|}{ Grain yield, tha ${ }^{-1}$} \\
\hline Farm 1 & 8.86 & 8.68 & 8.48 & 8.86 \\
\hline Farm 2 & 11.50 & 12.24 & 12.29 & 12.82 \\
\hline Farm 3 & 15.86 & 16.40 & 14.35 & 16.46 \\
\hline Farm 4 & 12.29 & 14.76 & 12.01 & 14.24 \\
\hline Average & 12.13 & 13.02 & 11.78 & 13.10 \\
\hline & \multicolumn{4}{|c|}{ Water productivity, $\mathrm{Kgm}^{-5}$} \\
\hline Farm 1 & 1.074 & 1.141 & 1.303 & 1.311 \\
\hline Farm 2 & 1.482 & 1.653 & 1.967 & 2.072 \\
\hline Farm 3 & 2.092 & 2.316 & 2.392 & 2.780 \\
\hline Farm 4 & 1.499 & 1.885 & 1.803 & 2.079 \\
\hline Average & 1.537 & 1.749 & 1.866 & 2.061 \\
\hline
\end{tabular}

Fayoum J. Agric. Res. \& Dev., Vol. 26, No.2, July, 2012 
The tested irrigation regimes seemed mostly to reduce maize grain yield in comparison with farmer practice, Table 3. In 2008 season, maize yield was reduced by 8.01 and $12.49 \%$ due to full and deficit ( 0.75 full irrigation) irrigation regimes, respectively, as compared with farmer practice. In 2009 season, the trend was differed where full irrigation exhibited higher maize grain yield value amounted to $7.34 \%$ while deficit irrigation still reducing the maize grain yield by $28.85 \%$, in comparison with farmer practice. So on water conservation, it is advisable to irrigate the maize crop at full irrigation regime (1.2 ETc). In this sense, Payero et al. (2008) showed that the differences in seasonal water requirements among irrigation depth treatments significantly $(\mathrm{P} \leq 0.05)$ affected dry matter production and yield components of maize. In addition, Javaid and Khalid (2009) found that the maximum maize yield of $2933 \mathrm{~kg} / \mathrm{ha}$ was obtained when plots were irrigated according to 0.75 Epan. Furthermore, Hamidreza Salemi et al. (2011) irrigated maize with 100, 80 and $60 \%$ of crop evapotranspiration and reported that the corresponding grain yield values amounted to 9450,9250 and $8377 \mathrm{kgha}^{-1}$, comparable with conventional irrigation $\left(9271 \mathrm{kgha}^{-1}\right)$. The authors added that $80 \%$ irrigation level is the most advantageous treatment when water is not limited. However, to save water and to get higher water productivity, $60 \%$ irrigation level treatment is recommended.

Data in Table 3 illustrated that water productivity (WP) for maize crop tended to increase under full and deficit irrigation ( 0.75 full irrigation) regimes in comparison with farmer practice. The increase percentages under full and deficit irrigation (0.75 full irrigation) regimes amounted to 24.36 and $43.13 \%$ in 2008 season and to 13.79 and $21.41 \%$ in 2009 one. Similar trend was reported by Hamidreza Salemi et al. (2011) who stated that WP for maize crop were increased as the water applied decreased where WP comprised 0.86 , $0.96,1.17$ and $1.42 \mathrm{kgm}^{-3}$ under conventional irrigation, 100, 80 and $60 \%$ of crop evapotranspiration, respectively. In general, Geerts and Raes (2009) had reviewed many research from around the world and confirmed that deficit irrigation is successful in increasing WP for various crops without causing severe yield reductions. In connection, Payero et al. (2008) found that water use efficiency was more sensitive to irrigation water and decreased explicitly with irrigation. Moreover, Chen et al. (2009) revealed that increase of irrigation amount resulted in more crop yields, but the water amount required to gain maximum WP was much less than that required for obtaining the maximum crop yield.

\section{3- Berseem}

\section{3.a. Raised -seed bed}

Data in Table 4 indicated, on four farms average basis, that growing berseem on raised- seed bed reduced the applied water quantity by $17.08 \%$, comparable with that applied with farmer practice. In connection, Shawan $\boldsymbol{e t}$ al. (2011) in Middle Nile Delta - Egypt, reported that seasonal applied water for berseem clover under bed-furrow irrigation practice ranged from 19.78 to $21.14 \%$, comparable with farmer practice. The potency of raised- seed bed practice in saving irrigation water with different crops were previously reported. Wentworth and Jacobs (2001), with maize crop, found that water saving using permenant beds irrigation amounted $31.1 \%$, comparable with furrow irrigation. In addition, Pramanik et al. (2009), found that, on an average, raised bed planting saved 37.5 to $50 \%$ of irrigation requirement for chickpea over flat bed planting.

Fayoum J. Agric. Res. \& Dev., Vol. 26, No.2, July, 2012 
RATIONALIZATION OF IRRIGATION WATER IN AGRICULTURAL... 26

Data in Table 4, on 4 farms average, exhibited higher fresh yield value comprised $22.20 \%$ due to growing berseem on raised -seed bed, more than that recorded under farmer irrigation practice. This finding could be attributed to proper soil moisture status in crop root zone which encourage water and nutrients absorption. In connection, EL-Marsafawy et al. (1998), stated that irrigation with $140 \mathrm{~cm}$ apart furrows, comparable with $70 \mathrm{~cm}$ apart ones, improved root environment which increased absorption media and encouraged growth characteristics for maize crop. On the contrary, Shawan et al. (2011) found that reduction in total fresh yield of berseem clover, on 4 cuttings basis, under bed-furrow irrigation practice ranged from 9.89 to $14.22 \%$, comparable with the farmer practice and attributed such reduction to less applied irrigation water under bed-furrow irrigation practice. In this sense, Lovelli et al. (2007) stated that water supply significantly modified the growth of root in relation to above ground plant part i.e. the amount of harvestable biomass of the forage in relation to total biomass.

Table 4: Applied irrigation water, fresh yield and water productivity for berseem under the adopted irrigation practices $2009 / 2010$ season

\begin{tabular}{|l|c|c|c|c|c|}
\hline \multirow{2}{*}{ Irrigation practice } & Farm 1 & Farm 2 & Farm 3 & Farm 4 & Average \\
\cline { 2 - 6 } & \multicolumn{5}{|c|}{ Applied Water (mm) } \\
\hline Farmer practice & 651 & 587 & 511 & 679 & 607.0 \\
\hline Raised - bed & 524 & 481 & 448 & 560 & 503.3 \\
\hline Full irrigation, 1.2 ETc & 601 & 554 & 492 & 641 & 572.0 \\
\hline Deficit irrigation, 0.70 ETc & 480 & 432 & 391 & 477 & 445.0 \\
\hline & \multicolumn{6}{|c|}{ Fresh yield (tonha ${ }^{-1}$ ) } \\
\hline Farmer practice & 99.476 & 84.762 & 86.905 & 99.452 & 92.645 \\
\hline Raised - bed & 125.000 & 100.00 & 102.833 & 125.000 & 113.208 \\
\hline Full irrigation, 1.2 ETc & 105.310 & 91.952 & 90.500 & 105.310 & 98.268 \\
\hline Deficit irrigation, 0.70 ETc & 90.095 & 80.167 & 80.405 & 90.167 & 85.209 \\
\hline & \multicolumn{7}{|c|}{ Water productivity $\left(\mathrm{kgm}^{-3}\right)$} \\
\hline Farmer practice & 15.28 & 14.44 & 17.00 & 14.65 & 15.34 \\
\hline Raised - bed & 23.85 & 20.79 & 22.95 & 22.32 & 22.48 \\
\hline Full irrigation, 1.2 ETc & 17.52 & 16.60 & 18.39 & 16.43 & 17.24 \\
\hline Deficit irrigation, 0.70 ETc & 18.77 & 18.56 & 20.56 & 18.90 & 19.20 \\
\hline
\end{tabular}

Water productivity is an efficiency term quantified as a ratio of product output (goods and services) over water input. The output could be biological goods such as crop grain, fodder....etc. So, data in Table 4 indicated that WP value seemed to increase under raised - seed bed irrigation by $46.54 \%$, comparable with the value recorded with farmer practice (4 farms average basis). Similar trend was found by Shawan et al. (2011) who reported that bed-furrow irrigation practice resulted in higher water productivity values (on total fresh yield basis) ranged from 6.01 to $29.84 \%$, as compared with farmer irrigation practice.

\section{3.b. Deficit irrigation}

As irrigation was practiced under full irrigation (irrigating at $1.2 \mathrm{ETc}$ ) and deficit irrigation (irrigating at $0.7 \mathrm{ETc}$ ) regimes, the reductions in water applied reached 5.77 and $26.69 \%$ less than that obtained with farmer practice.

Fayoum J. Agric. Res. \& Dev., Vol. 26, No.2, July, 2012 
In connection, Kirda (2000) stated that the proper application of deficit irrigation practices can generate significant savings in irrigation water allocation.

Data in Table 4 revealed that irrigating berseem crop according to 1.2 ETc (full irrigation regime) resulted in fresh yield value reached $6.07 \%$ higher than that obtained with farmer practice. Nevertheless, irrigating at $0.70 \mathrm{ETc}$ (deficit irrigation regime) exhibited lower fresh yield value comprised 8.03 less than that reported under farmer irrigation practice. In connection, Lazaridou, Martha and Koutroubas (2004), at Drama, Macedonia, Greece, stated that water stress resulted in a reduction of the above ground dry biomass to one third of irrigated berseem plants ( $2.3 \mathrm{vs} 6.8 \mathrm{~g} / \mathrm{plant})$.

Data in Table 4 illustrated that irrigating berseem according to either 1.2 (full irrigation) or $0.7 \mathrm{ETc}$ (deficit irrigation) regimes resulted in WP values (on fresh yield basis) reached 12.39 and $25.16 \%$ higher than that obtained with farmer practice. In this sense Lazaridou, Martha and Koutroubas (2004) stated that water stress resulted in an increased water use efficiency for irrigated berseem crop. Moreover, Ouda et al. (2010) stated that water productivity for berseem was gradually increased under all deficit irrigation treatments e.g. 95, 90, 85, and $80 \%$ of full irrigation.

On conclusion, in order to save water resources and to accomplish higher water productivity for wheat, berseem clover and maize crops it is advisable to grown such crops on raised - seed bed which proved to an effective practice in water conservation. In addition, deficit irrigation technique, at $0.70 \mathrm{ETc}$ for wheat and berseem crops and at $0.75 \mathrm{ETc}$ for maize crop, proved to be effective in saving water and improving water productivity for such crops.

\section{REFERENCES}

Abdou, S.M.M.; R.M. F. Farrag ; M.F.I. EL- Akram and M.R.K. Ashry (2011). Water relations and yield of wheat under different $\mathrm{N}$ - fertilizer forms and scheduling irrigation. J. Soil. Sci. and Agric. Eng., Mansoura Univ., 2(1); 25- 41.

Ahmad, M.; A. Ghafoor ; M. Asif and H.U. Farid (2010). Effect of irrigation techniques on wheat production and water saving in soils. Soil \& Environ. 29(1): $69-72$.

Chen, C.; Wang, E., and Yu, Q. (2009). Modeling the effects of climate variability and water management on crop water productivity and water balance in the North China Plain. Agricultural Water Management, 10.

EL-Marsafawy, Samia M.; A.Y Salib; M.A. Aly and H.M. Eid (1998). Row width and nitrogen levels impacts on water relations, growth and yield of maize crop.Third Conference of Meteorology and Sustainable development Cairo, Egypt.

English, M.J.; J.T. Musick and V.V. Murty (1990). Deficit irrigation. In: G.J. Hoffman, T.A. Towell \& K.H. Solomon, eds. Management of farm irrigation systems, St. Joseph, Michigan, United States of America, ASAE.

Fahong Wang; Ling'an Kong; Ken Sayre; Shengdong Li; Jisheng Si; Bo Feng and Bin Zhang (2011). Morphological and yield responses of winter wheat (Triticum aestivum L.) to raised bed planting in Northern

Fayoum J. Agric. Res. \& Dev., Vol. 26, No.2, July, 2012 
RATIONALIZATION OF IRRIGATION WATER IN AGRICULTURAL.... 28

China. African Journal of Agricultural Research Vol. 6(13) :29912997.

Fahong.W.; W. Xuqing and K. Sayre (2004). Comparison of conventional, flood irrigated, flat planting with furrow irrigated, raised bed planting for winter wheat in China. Field Crops Research 87 (2004) 35-42.

Geerts, S. and Raes, D. (2009). Deficit irrigation as an on-farm strategy to maximize crop water productivity in dry areas. Agricultural Water Management, 96, 1275-1284.

Ghani Akbar A; Greg Hamilton B. and Steven Raine C. (2010). Permanent raised bed configurations and renovation methods affect crop. $19^{\text {th }}$ World Congress of Soil Science, Soil Solutions for a Changing World, Brisbane, Australia.

Hamidreza Salemi, Mohd. Amin Mohd. Soom, Teang Shui Lee, Mohd Kamil Yusoff and Desa Ahmad (2011). Effects of Deficit Irrigation on Water Productivity and Maize Yields in Arid Regions of Iran. Pertanika J. Trop. Agric. Sci. 34 (2): 207 - 216 (2011).

Javaid A. Tariq and Khalid Usman (2009). Regulated deficit irrigation scheduling of maize crop, Sarhad J. Agric. Vol.25, No.3.Khan, M. A.;

Muhammad Shafeeq and Awan I.U. (2007). Water and energy inputs for wheat production under permanent raised beds. Sarhad J. of Agriculture. Vol.23 (3).

Kirda, C. (2000). Deficit irrigation scheduling based on plant growth stages showing water stress tolerance. Deficit irrigation practices in FAO Water Report № 22.

Lazaridou, Martha and S.D. Koutroubas (2004). Drought effect on water use efficiency of berseem clover at various growth stages. $4^{\text {th }}$ International Crop Science Congress Brisbane, Australia.

Lovelli, S.; M. Perniola; A. Ferrara and T. Di Tommaso (2007). Yield response factor to water $\left(\mathrm{K}_{\mathrm{y}}\right)$ and water use efficiency of Carthamus tinctorius L. and Solanum melongena L. Agricultural Water Management, 92:73-80.

Ouda, Samiha A.; R. Abou Elenin and M.A. Shreif (2010). Simulating the effect of deficit irrigation on Egyptian clover yield and water productivity. Fourteenth International Water Technology Conference, IWTC 14 2010, Cairo, Egypt

Payero, O.; Tarkalson, D.; Irmak, S.; Davison, D. and Petersen, L. (2008). Effect of irrigation amounts applied with subsurface drip irrigation on corn evapotranspiration, yield, water use efficiency, and dry matter production in a semiarid climate. Agricultural Water Management, 95, 895-908.

Smith M. (1992). A computer program for irrigation planning and management. FAO Irrigation and Drainage Paper No. 56, FAO Rome.

Shahwan, Shadia M.; Mohamed M. Ewaise; Zaghloul M. Marie and Hamadah H. Abdel-Maksoud (2011). Impact of irrigation practice, P-fertilization rate and their interaction on growth, yield, yield quality, P- use efficiency and water productivity for berseem clover on vertisols. J. Soil. Sci. and Agric. Eng., Mansoura Univ., 2(1): 25- 41.

Stegman, E.C.; J.T. Musick and J.I. Stewart (1980). Irrigation water management. In: M.E. Jensen ed. Design and operation of farm irrigation systems. St. Joseph, Michigan, United States of America, ASAE

Fayoum J. Agric. Res. \& Dev., Vol. 26, No.2, July, 2012 
Stone, J.F.H. E. Reeves and J.E. Garton (1982). Irrigation water conservation by using wide-spaced furrows. Agricultural Water Management, Volume 5, Issue 4, 309-317.

Walker, W.R. and G.V. Skogerboe (1987). Surface Irrigation: Theory and Practice. Prentice-Hall, Englewood Cliffs, New Jersey.

Wentworth, S. and B. Jacobs (2001). Sustainable Irrigated Maize on Sodic Soils in the Lachlan Valley. Proceedings of $10^{\text {th }}$ Australian Agronomy Conference, Australian Society of Agronomy.

Zwart, S.J. and Bastiaanssen, W.G.M. (2004). Review of measured crop water productivity values for irrigated wheat, rice, cotton and maize. Agricultural Water Management, 69, 115-133.

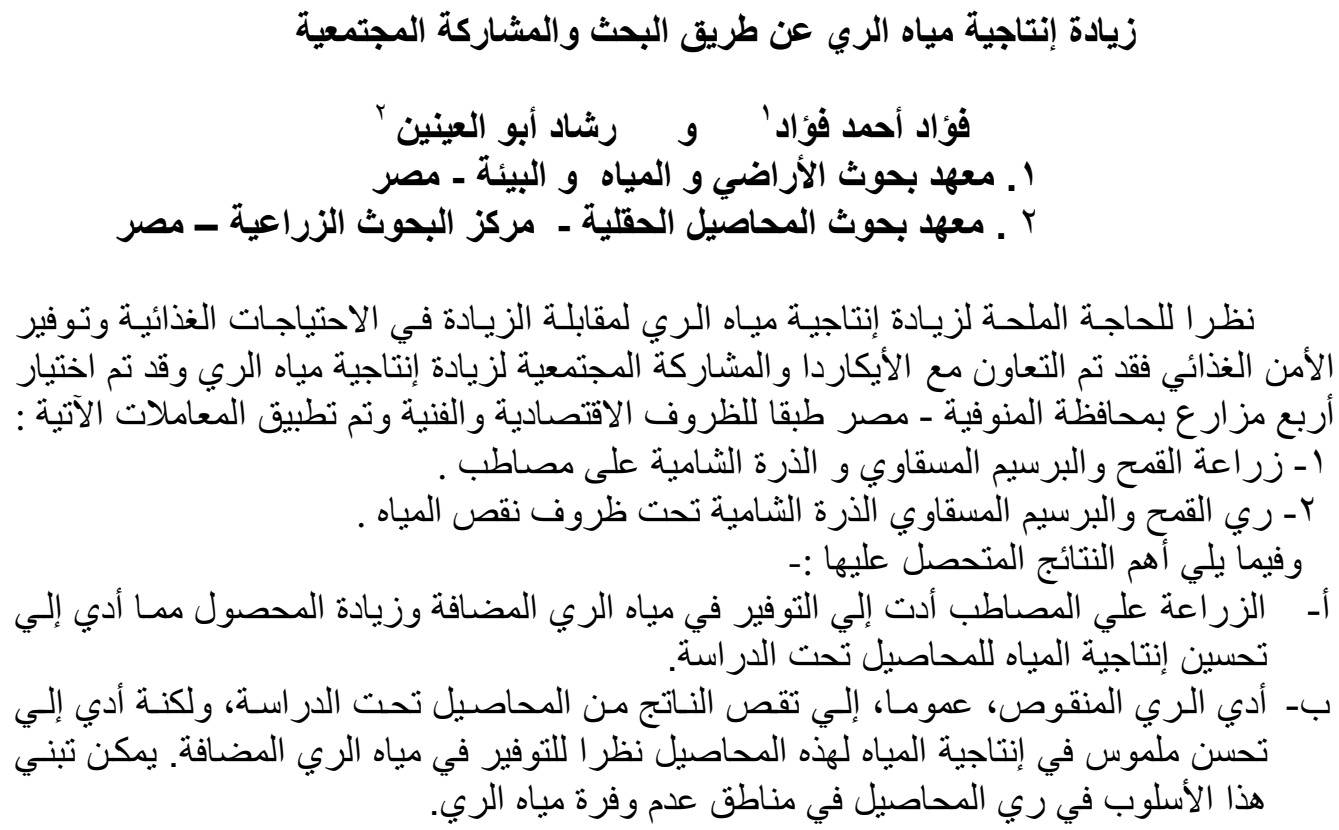

